\title{
The Disappearing Natterjack
}

\section{Keith F. Corbett and Trevor J. C. Beebee}

The natterjack toad is decreasing rapidly in Britain. This is particularly true of its largest population on the dunes of south-west Lancashire, where developments in the form of houses, roads and a holiday camp have deprived it of habitat. Even more serious, say the authors, who have made a survey of this toad in Britain for WWF, is the drying out of the dune slacks, the freshwater pools where the natterjacks breed, as a result of the lowering of the water table by drainage and abstraction. The artificial substitutes provided so far are not adqeuate and the authors urge the need to create large and suitable breeding pools for the toads.

The natterjack toad Bufo calamita, one of only six indigenous amphibians in the British Isles, is strictly confined to sandy areas such as coastal dunes and inland heaths. The result is a disjunct and localised distribution that makes this toad particularly vulnerable to habitat changes, for, like most temperate herpetofauna, it can only move within a limited range and cannot survive fragmentation or even temporary loss of habitat as can birds, insects and seed plants. Being the only English amphibian on the edge of its range, it provides an interesting ecological study of limiting environmental factors, and is therefore of considerable scientific importance. The male's distinctive and penetrating calls - the loudest of the European amphibia - have earned the species a place in folklore, with local names such as Thursley thrush and Birkdale nightingale.

\section{Status Changes}

A recent survey of the natterjack, sponsored by the World Wildlife Fund (1), shows that there has been a drastic reduction in numbers. Since recordings were first taken (2), it has totally disappeared from south-west England and Wales, and probably also from south-east England which was a noted recent stronghold. Only four small colonies survive in East Anglia, a range decrease of 90 per cent, only one vestigial population is left in the north-east, and the decline at Irish stations (in Kerry) has been considerable. The only regions with anything like a natural distribution are north-west England and the Solway (Lancashire to Dumfries) and even here the area of by far the largest British colony, south-west Lancashire, has decreased dramatically and continues to do so unchecked.

The natterjack's predicament is the result of gross interferences with its habitat. Its position as a rare and endangered species in Britain has been recognised since 1970 by both the British Herpetological Society and the Nature Conservancy, which together formulated a conservation policy that is now being pursued not only for the natterjack, but also for the sand lizard and smooth snake. Unfortunately, however, it has so far proved impossible to instigate any realistic conservation in Lancashire, where the toad and its habitat continue to decline.

The sand dune system of south-west Lancashire extends from Crosby north to Southport in a continuous 11 -mile coastal strip, in places up to a mile wide. 
The dunes rest on the seaward side of a gently sloping peat bed which continues inland as the low-lying 'mosses'. The natterjacks occur over the whole dune area of more than eight square miles - the second largest British natterjack habitat at Ravenglass covers only 1.5 square miles - and the Lancashire area's importance is enhanced by the freshwater breeding pools ('slacks'), covering 30 per cent of the dune area - at Ravenglass they normally occupy less than five per cent. The large extent of suitable dunes and the high proportion of breeding slacks (a limiting factor in natterjack population size) enabled the Lancashire area to support enormous numbers of natterjacks, estimated in the 1930's at many hundreds of thousands $(3,4)$. There was a small decline between 1930 and 1960 due to minor habitat infringements, but the major decline started after 1960 and has since accelerated, until by 1974 the population had decreased to under 5000 . The construction of a new coast road, a large holiday camp and housing estates has eliminated natterjack habitat and fragmented the remaining Ainsdale and Birkdale hills, but the most significant factor has undoubtedly been the drying out of the breeding slacks.

The housing estates have substantially reduced the dune catchment area, and the water table is no longer supplemented by the open streams, all now piped, which formerly flowed through the dunes to the foreshore. Two major drainage schemes on the adjacent mosses in the early 1960s have been so successful that they have lowered the water table by four feet. These schemes were designed to remove 50 per cent of the incident rainfall, regardless of drought years when their effects are likely to be most critical. In addition, the abstraction of drinking water from the underlying aquifer has exceeded its capacity and it now produces saline water more than six miles inland. In effect, normal outflow of fresh water has been reversed, and no viable natural slacks now remain anywhere in the area. The effects on slack levels have been observed over many years, but recent low-rainfall years have fully exposed the extent of the problem. Other dune-slack dependent species have suffered with the natterjacks: the common and arctic terns have gone, and among invertebrates the rare beetle Carabus nitens has disappeared. The winter wildfowl migrations, once a well known feature of the dune slacks, have ceased. Among the plants, the very rare Scirpus americanus has virtually disappeared.

Natterjack breeding success has been minimal since 1970, and the toads are now limited to three remaining types of pool: 1 . the slack remnants which always dry up well before metamorphosis, except for the Sands Club lake permanent slack, the only viable breeding site left; 2 . large deep pools, such as occur on local golf courses and the national nature reserve's sand extraction site, which are unsuitable for natterjacks because the water temperature is never high enough at metamorphosis; and 3. small water holes, such as those dug by the Nature Conservancy and the Lancashire Naturalists' Trust, which are often badly sited, subject to intensive collection, and, even if left undisturbed, both too few and too small to support significant numbers of tadpoles through to metamorphosis. Eight small pools created in the national nature reserve are unfortunately of type 3 ; in addition they are all in pinewood areas least populated by natterjacks so have hardly been used.

The water shortage has resulted in widespread amphibian migrations in search of breeding sites, with some heavy losses due to road mortality. Arrival at almost any water precipitated mating and spawning. The naturalists' trust 
believed that the large numbers spawning at the second type of pool was a direct indication of breeding success (5), but no estimates were made of the numbers of larvae the pools could support or of the previous productivity of the same number of adults using the large shallow slacks.

\section{Conservation}

So far, attempts to remedy the situation have been minimal. The importance of this, the largest site in the country, and the possibility of a direct water table link between the dunes and the mosses are not appreciated, and the naturalists' trust's report, invited by and made with the assistance of the Nature Conservancy, unfortunately suggests that the situation is satisfactory. The Nature Conservancy failed to oppose the dune developments - the coast road, piping of the dune streams, the Pontins holiday complex, and even the current plans to extend Pontins by developing the Sands Club lake. The report (5) presents the results of a status survey, but the work was carried out by people without experience of amphibian ecology who failed to locate the largest remaining breeding population at the Sands Club lake. Their definitions of medium (5-10 pairs) and large (20 or more) breeding sites of pool types 2 and 3 (see page 48) cannot be compared with the recent breeding populations of hundreds of pairs using each of the type 1 slacks. The trust's suggestion that slack dessication, if permanent, will lead to a more localised natterjack population is exceedingly optimistic; extinction is far more likely.

\section{Recommendations}

Meaningful remedial conservation measures are urgently needed for this population, and should include:

(1) Rigorous opposition by all the conservation organisations involved to all further dune development.

(2) The mechanical re-creation of large slacks all along the dune system, both on and off the national nature reserve, as urged by the British Herpetological Society's Conservation Committee as long ago as 1970. These should be at least as large as the one the Nature Conservancy excavated successfully for natterjacks on their East Anglian national nature reserve at Winterton dunes. Only the immediate restoration of open water can assure the future of Bufo calamita, and indeed of many other freshwater-dependent species.

\section{Acknowledgments}

The authors wish to thank Mr R. Wagstaffe and Mr S. H. Smith for access to their extensive records relating to the SW Lancashire dunes.

\section{References}

1. BEEBEE, T.J.C. 1975. The Natterjack toad in Britain; a study of past and present status. Brit. J. Herpetol. (in press).

2 TAYLOR, R.H.R. 1948 Distribution of the British Reptiles and Amphibia, with notes on species recently introduced. Brit. J. Herpetol., 1, 1-38.

3 HARDY, E. 1939 A rare toad (natterjack). Field, 174, 415.

4 PRESTT, I., COOKE, A.S. and CORBETT, K.F. 1974 The British Amphibians and Reptiles, in: Systematic Association Special Volume No. 6, The Changing Fauna and Flora of Britain. Ed. D. L. Hawksworth; Academic Press, London. pp. 229-254.

5 SMITH, P.H., HARRIS, J.I. and HANCOCK, E.G. 1974 The Natterjack Toad in Southwest Lancashire, 1972. Nature in Lancashire, $4,44$. 